\title{
Lisans Eğitiminde Mutfak Zanaatları ve Gastronomi
}

\section{GiRiş}

Rekreasyon bireylerin yaşamak için yapması gereken uğraşların dışında kalan zaman diliminde, kendi istekleri ve tercihleri doğrultusunda gerçekleştirdiği faaliyetler olarak ele alınabilir. Diğer bir ifade ile yaşamamız için gerekli olan besinleri almak için yemek yememiz veya enerjimizi toplayabilmek için uyumamız, normal şartlar altında bir boş zaman faaliyeti olmamaktadır. Öte yandan bireyin kendi iradesi ile zevk ve doyum sağlamak amacıyla boş zamanında yaptığ etkinlikler, rekreasyon olarak değerlendirilebilir (Karaküçük 2008). Bir akşamüstü eski dostların buluşup, bir çilingir sofrası etrafında dostluklarını kuvvetlendirip yemek yemeleri rekreatif bir faaliyet olarak ele alınabilir. Oysaki hayatımızı sürdürmek için yemek yeme zorunluluğumuz, burada hoş bir sohbet ile birleştiğinde rekreatif bir faaliyet olarak ortaya çıkmaktadır. Özellikle konforlu bir ortamda damak tadimıza uygun yiyecekleri yememiz ve içecekleri içmemiz, hepimizi keyiflendirir. Bu kapsamda rekreatif faaliyetler içinde beslenmemizin yeri farklı olmaktadır. Her canlının hayatta kalması için beslenmesi gerekmektedir. İnsanın var olduğu ilk çağlardan bu yana beslenme sistemini geliştirmesi, hem hayatta kalma çabasının bir parçası hem de yaşamını daha kaliteli hale getirmesinin bir yansımasıdır. İnsanın beslenme şekilleri ve yemek kültürlerini algılayabilmek için atalarımızın nasıl yaşadıklarını, bilimsel yaklaşımlar çerçevesinde değerlendirmek gerekir. Avcı-toplayıcı olarak yaşayan ilk atalarımız, hayatlarını sürdürebilmek için daha çok bitkiler ile beslenmelerini sağlamakta ve bir nevi günümüz diyetlerini uygulamaktaydılar
(Dorey 2018). İlk başlarda diğer hayvanlarında yaptığı gibi taze ve çiğ yiyecekleri tüketiyorlardı. Her ne kadar protein sağlamak için et yemesi gerekse de eti elde etmesi ve bu çiğ eti sindirmesi, meyve-sebzeyi elde etmesi ve sindirmesine göre daha meşakkatliydi. Bununla birlikte insanoğlunun ateşi keşfetmesiyle, yiyecek yeme alışkanlıkları ve buna bağlı olarak evrim süreci, birden farklı bir kulvara geçmiştir.

Yapılan araştırmalar atalarımızdan Homo Erectusun yaklaşık 1,8 milyon yıl önce yiyecekleri ateşle pişirmeye başladığını göstermektedir (Wong 2013). Yiyeceklerin pişirilmesi hem tat olarak farklılık yaratırken, hem de daha kolay sindirilmelerine olanak taniyordu. Buna ek olarak pişirme esnasında, insana zararlı olabilecek diğer mikrop ve bakteriler de yok ediliyordu. Bu pişirme sürecinin devamlılı̆̆ım sağlanması için düzenli olarak ateşin yakılabilmesi gerekmekteydi. Bu nedenle yemeklerin pişirilmesinde, atalarımız için fırın-ocakların ayrı bir önemi bulunmaktaydı. Arkeologların çalışmaları düzenli olarak yiyecek pişirmede kullanılan fırın ve ocakların, 300.000 yıl önce ilk kez Neanderthaller tarafından kullanıldığını ortaya koymaktadır (ShahackGross vd. 2014). Atalarımız ateşin yemeklerde kullanılmasını keşfettikten sonra, sadece fırın ve ocaklarda yiyeceklerini kuru kuruya pişirmemişler, aynı zamanda tatlarını farklılaştırmak için değişik yöntemlere de başvurmuşlardır. Neanderthallerin dişlerindeki tartarlar incelendiğinde, yiyeceklerini şifalı otlarla baharatlandırdıkları, diğer bir ifade ile damak tatlarına yönelik yemeklerini hazırladıkları, pişirdikleri ve yedikleri saptanmıştır (Lawton 2016). 


\section{GASTRONOMI}

İnsanı diğer canlılardan farklı kılan belki de en büyük özelliği, hayatını daha keyifli hale getirmek için yaptığı sürekli çabalardır. Yaşamamız için elzem olan beslenmeyi daha keyifli kılmak adına, yaşadığımız alanlardaki yenilebilir bitki ve hayvan çeşitliliğine bağlı olarak, çok farklı beslenme şekilleri ve yemek kültürleri ortaya çıkmıştır. İlk medeniyetlerin oluştuğu en önemli merkezlerden biri olan Mezopotamya, bitki ve evcil hayvan çeşitliliği bakımından diğer bölgelere göre çok daha şanslı idi. Anadolu'da avcı toplayıcı toplumdan tarım toplumuna geçiş, gıda yetiştirme ve depolama başarısına bağlı olarak, daha düzenli toplulukların ve toplumların oluşmasına olanak tanımış, yemek alışkanlıklarımızı da değiştirmiştir. Buna bağlı olarak aynı topraklarda yaşayan Anadolu uygarlıklarının yeme ve içme kültürleri de birbirlerinden etkilenmiştir.

Yeme içme ile ilgili olarak ülkemizde son dönemde sıkça duyduğumuz gastronomi kelimesinin kökeni, yine Anadolu medeniyetleri ile iç içe olan antik Yunan kültürüne (hatta Lidya) dayanmaktadır. Her ne kadar ilk kaynağı (M.S. 200) şu an elimizde olmasa da yazılı kayıtlara göre gastronomi kelimesini ilk açıklayan kişi Athenaeus'tur. Athenaeus'un yazmış olduğu kitabın bir kısmı ancak 1927 yılında ele alınmış ve İngilizce'ye çevrilmiştir. Etimolojik olarak gastronomi kelimesi "gastro" ve "nomos" kelimelerinden oluşmakta ve "gastro" ağızdan başlayan, tüm sindirim sistemimizi kapsaya mide olarak, "nomos" ise kural veya düzenleme olarak ele alınmaktadır. Tarihsel ve etimolojik olarak gastronomi; neyin nerede, ne zaman, hangi şekilde, hangi kombinasyonlarda yenileceği ve içileceği konusunda tavsiye ve rehberlik verilmesi anlamında kullanılmaktadır (Santich 2004). Gastronomi sözlüklerden Merriam Webster'da (2019) "iyi yemek yeme sanatı veya bilimi", Cambridge'de (2019) "iyi yemek hazırlama ve yeme sanatı veya bilgisi", Oxford' ta (2019) "iyi yemek yeme, seçme ve yapma sanatı veya pratiği", Collins'de (2019) "iyi yemek hazırlama ve değerlendirme ile ilgili etkinlik ve bilgi" olarak tanımlanmaktadır.

Sözlükler genel olarak gastronomiyi iyi yemek yeme sanatı ve/veya bilimi olarak tanımlamakla birlikte, son dönemli çalışmalarda sadece yemek yeme faaliyetini değil içine üretim kısmı dahil hazırlama, pişirme ve sunma faaliyetini de alan daha geniş bir anlamı kapsayarak kullanıldığ 1 gözlemlenmektedir. Bununla birlikte tanımın özünde neyin, niçin, nerede, ne zaman ve nasıl $(5 \mathrm{~N})$ yenileceği ve içileceği yer almaktadır. Öte yandan genişletilen tanım ele alındığında, yemek ve içeceklerin hazırlanması için gerekli malzemelerin seçimi, satın alınması, depolanması ve saklanması, üretim yerlerinin planlanması ve hazırlanması istihdamının sağlanması, işgücünün planlanması, örgütlenmesi, koordine ve kontrol edilmesi, ön hazırlıklarının yapılması, gerektiğinde pişirilmesi ve pişirme yöntemleri, taşınmasi, sunumu, sunum alanının tasarımı, atmosferi, ambiyansı ve bu ürünlerin pazarlanması, muhasebeleştirilmesi ve finansmanı bu sürecin içinde yer almaktadır. İşte bu son uzun cümle, gerçek fiili durumu ortaya koymaktadır. Tüm bu fonksiyonlar ve süreçler bir araya geldiğinde, sanki gastronominin anlamı ilk ve ana tanımında yer alan "neyin nerede, ne zaman, hangi şekilde, hangi kombinasyonlarda ne yenileceği ve içileceği konusunda tavsiye ve rehberlik verilmesidir" açıklamasının ötesine geçmekte ve yiyecek-içecek işletmeciliğine doğru yönelmektedir.

\section{GASTRONOMI VE MUTFAK ZANAATLARI}

Bu çalışmada ülkemizde gastronomi bölümlerinde verilen lisans eğitimlerinin, gastronomi tanımından yola çıkılarak sağlıklı bir şekilde yürütülüp, yürütülemeyeceği sorgulanacaktır. Ülkemizde Turizm İşletmeciliği ve Otelcilik Yüksekokullarının Turizm Fakültesine dönüşmesi sürecinde, bu okullarda yer alan bölümlerin yapılarında ve adlarında da değişimler olmuştur. Bunlardan biri de eskiden Yiyecek-İçecek İşletmeciliği olarak açılan bölümlerin artık Gastronomi ve Mutfak Sanatları olarak yeni fakültelerde yer almasıdır. 2018-19 öğretim yılında öğrenci alan ilgili bölümler incelendiğinde kamu üniversitesinde dört adet Yiyecek-İçecek İşletmeciliği bölümü, 32 adet Gastronomi ve Mutfak Sanatları bölümü ve 33 adet özel üniversitede toplamda 65 adet Gastronomi ve Mutfak sanatları bölümünün olduğu görülmektedir. Bu sayının artarak devam etme 
olasılığı da yüksek gözükmektedir. Yiyecek-İçecek İşletmeciliği bölümlerinde bir artış gözükmemekte, akademisyenlerin Yiyecek-İçecek İşletmeciliği bölümü yerine Gastronomi ve Mutfak Sanatlarını tercih ettikleri gözlemlenmektedir.

Kelime anlamiyla gastronomi "iyi yemek yeme sanatı ve/veya bilimi" ise öğrencilerin yemeğin nasıl yenileceğini ve tadılacağını öğrenmesi gerekmektedir. Diğer bir ifade ile belirli bir düzeyde tadımcı (gastronom) olabilmelidirler. Tadımcılığın sadece eğitim ile gerçekleştirilebileceğini düşünmek yanlış olabilir. Lisans eğitiminden tadımcı çıkarabilmek çok zordur. Bu hem damak tadının her kişi için çok farklı olmasından, hem de okulların bütçelerinden dolayı pek olanak1 görülmemektedir. Zaten mevcut bölümlerde yemek yemekten ziyade, yemek hazırlamasina yönelik eğitim verilmektedir. Hal böyle olunca gastronomiden bahsetmek te doğru olmamaktadır. Zaten hazırlanan bölümlerin müfredatları incelendiğinde, ağırlığın gastronomiden çok mutfak zanaatlarına verildiği görülmektedir. Yurtdışında mutfak sanatları dense de ülkemizde karşılığını çok daha iyi olduğu mutfak zanaatları bölüm adı olarak değerlendirilebilirdi. Öte yandan gastronomiye (tadım) yönelik uygulamalı eğitim tam verilemese de bölüm adı Gastronomi ve Mutfak Sanatları olarak belirlenmiştir.

Bölümlerin müfredatları incelendiğinde, bu bölümleri aslında Yiyecek ve İçecek İşletmeciliği bölümlerinden farklılaşamadığ 1 ve hatta eğitimlerinin daha çok yiyecek içecek işletmeciliğine yönelik olarak kurgulandığ anlaşılmaktadır. Pazarlama, tüketici davranışı veya diğer bazı derslerde olduğu gibi dersinin başına gastronomi eki getirildiğinde (Gastronomide Satış ve Pazarlama gibi), dersin Gastronomiye özel bir ders olduğu düşünülmüştür. Oysaki derste anlatılan satış ve pazarlamadır, sadece başına gastronomi getirilmiştir. Gastronomi ve Mutfak Zanaatları ile ilgili kamu üniversitelerinde yer alan müfredatlar incelediğinde, durum ortaya daha net bir şekilde çıkmaktadır. Eğer dersleri sadece Gastronomi ve Mutfak Zanaatlarına özgü olarak değerlendirirsek, kamu üniversitelerinde bu bölümlerde okuyanların dört yıllık eğitimleri süresince ortalama olarak toplamda 56 ders içinde 19 adeti, diğer bir ifade \% 33'ü doğrudan Gastronomi ve Mutfak Zanaatları ile ilgilidir (Üniversitelerin müfredatları incelenebilir). Diğer dersler diğer turizm programlarıyla yüksek benzerlik göstermektedir. Buradan hareketle mezunların alanlarına yönelik yeterli donanım ile çıkmaları pek kolay olmayacaktır.

Eğitimi sadece kavramsal ve kuramsal olarak değil aynı zamanda uygulama ile de bütünleştirmek gerekmektedir. İyi bir mutfak zanaatkârı olmak için uygulamada neler gereklidir sorusunun yanıtı verilebilirse, buna yönelik iyi bir eğitim planlanabilir. Aslında dilimizde genelde her iş için kullanılan bir deyim "işi mutfağında öğrenmek" tam da bu alan ile ilgilidir. İyi bir eğitim için ilk olarak akla iyi bir mutfak, iyi birden fazla aşçı (soğukçu, sıcakçı, pastacı, ızgaracı vd.) ve elbette yemek için gerekli malzemeler gelmektedir. İyi bir mutfağın oluşturulması ciddi bir bütçe gerektirdiği gibi, iyi aşçı eğitimcilerin bulunmasına da ihtiyaç vardır. Bunları sağlamak bu alan için hiç te kolay değildir. Ülkemizdeki programların kaçında Mişlen (Michelin) yıldızlı aşçı, ders vermektedir sorusunun yanitı, programların konuya nasıl yaklaştıkları konusunda fikir sahibi olmamızı sağlayacaktır. Elbette bu düzeyde aşçı istihdam edilmesi çok zordur ancak eğitim kalitesi açısından, bu kalitede aşçıların yetiştiği yerlerde eğitim almış, en azından beş yıldızlı otel deneyimi olan aşçıların programlarda yer edinebilmesi gereklidir. Bu beceri ve tecrübeye sahip kişilerin istihdamı da ciddi bir bütçe gerektirmektedir.

Farklı mutfak kültürlerine yönelik verilecek eğitim içinde yine farklı kültürlerin damak tad1na göre alınması gereken malzemeler olduğu unutulmamalıdır. Varsayalım ki lisans eğitimini verecek olan okulda tam teşekküllü bir mutfak olsun ve burada ana yemek olarak istakoz hazırlanmasına yönelik bir ders verilsin. Acaba 1stakoz alabilecek bütçe planlanması, kaç okulumuzda sağlıklı bir şekilde yapılabilir. Belki bir 1stakozun maliyetini karşılanabileceği düşünülebilir ancak farklı mutfak kültürlerine yönelik verilecek eğitimin içinde çok farklı ve fiyatları da yabana atılamayacak birçok malzemenin alınması gerekmektedir. Karamelize bildırcın veya kurutulmuş kaz ciğerinin nasıl hazırlanılacağı- 
nı öğretebilmeniz için bunlara yönelik mutfakta uygulamalı eğitimlerin yapılması gerekmektedir. Öğrenci sayınıza göre malzemenizin alınması gerekliliğinin de göz ardı edilmemesi gerekmektedir. Gastronomi eğitiminde sadece yemeklerin nasıl hazırlanacağı değil, bunların nasıl yenileceğinin ve yanında nelerin içilebileceğinin de anlatılması gerekmektedir. 60 öğrencili bir sınıfa az pişmiş biftek ile çok pişmiş bifteğin nasıl hazırlanacağını anlatıp, bunlarla birlikte nelerin içilebileceğini uygulamalı gösterebilmek, ne yazık ki kamu ve birçok özel üniversite için pek mümkün değildir. Tüm bunların kısıtlı bir bütçeyle yapılması ne kamu üniversiteleri ne de özel üniversiteler için istisnaları hariç olası gözükmemektedir. Ancak Mavi Kurdele (Le Cordon Bleu) sertifika eğitimini verebilecek, ciddi yıllık malzeme bütçesi olan (Y1llık 300.000.- TL) istisnai üniversitelerimizin de bulunduğu bir gerçektir.

\section{SEKTÖREL YAKLAŞIMLAR (DE FACTO)}

İzmir'de Gastronomi ve Mutfak Sanatları bölümünü kurmak isteyen bir üniversite, Çeşme ve Alaçatı'da yer alan beş yıldızlı otellerin insan kaynakları (IK) yöneticileri ile bu alana yönelik ihtiyaçlarını belirleyebilmek ve açabileceği yeni bölümün altyapısını daha gerçekçi bir şekilde oluşturabilmek amacıyla iletişime geçmiştir. Sektörün bu konudaki düşünceleri görüşülen beş İK yöneticisinde hemen hemen aynıdı. Genel olarak vurguladıkları; öğrencilerin stajları ile ilgili kendilerini nüfuzlu kişilerin sıkça arayıp staj yeri ayarlamaya çalıştıklarını, staja kabul edilenlerin genel olarak bilgi, beceri ve uygulama açısından zayıf oldukları, alanda çalışmaya başladıktan sonra çok zorlandıkları ve çok sayıda Gastronomi ve Mutfak Sanatları bölümü olduğu yönündedir. Bu nedenle ilgili üniversiteye böyle bir bölümü açmamaları yönünde bilgi aktarmışlardır.

Çalışmanın yazarı Antalya'da iki beşli yıldız otel yöneticisi ve iki İK yöneticisi ile Gastronomi ve Mutfak Sanatları mezunlarının istihdam olanakları ile ilgili görüşme yapmıştır. Görüşme yapılan dört yönetici de Gastronomi ve Mutfak Sanatlar1 eğitimi alan öğrencilerin, çalışma isteklerinin yüksek olmadığını belirtmişlerdir. Yöneticiler bu alanda eğitim gören öğrencilerin bilinçli tercih- ler ile bölümlerini seçtiklerini düşünmediklerini belirtmişlerdir. Medyanın bu yöndeki yayınlarının (dizi, film, şov vb.) öğrencilerin tercihlerinde etkili olduklarını vurgulamışlardır. Özellikle bir İK yöneticisi bu bölümden mezun olanların kendilerini kısa bir gelecekte "Issız Adam" gibi çalışacaklarını düşündüklerini belirtmiştir. Dört yönetici de beş yıldızlı bir otelde en zor çalışma alanlarından birinin mutfak olduğunu belirtmişlerdir. Mutfak zaman ve mekân sıkışıklığından doğan sosyal sorunların en çok yaşandığı ana bölümlerden biri olurken, otelde iş kazlarının en çok yaşandığ 1 yerlerden biridir. Yöneticilerin özelikle üstünde durduğu üzerine kaynar bir s1vı dökülmemiş veya sıçramamış, vücudunun bir yerini kesmemiş bir aşçı bulmanın mümkün olmadığıdır. Zamansal sıkışıklık, çalışanlar üzerinde fazlasıyla baskı yaratmakla, bunun sonucu olarak hem iş kazaları hem de sosyal sorunlar artmaktadir.

Yöneticilerin üzerinde 1srarla durduğu, bu alanda çalışacak kişilerin çok yoğun bir tempoda sürekli çalışma becerisine sahip olmaları yönündedir. Gastronomi ve mutfak sanatları bölümünde okuyan öğrenciler staja geldiklerine, çalışma koşulları hakkında çarpıcı gerçekleri de öğrenmekte ve bunun sonucu olarak bir kısminda hayal kırıklığının olduğu belirtilmektedir. Görüşülen yöneticiler sektörde mutfakta çalışacak kalifiye elemanlara ihtiyaç olduğu ama mevcut eğitim ile bunları sağlamanın kolay da olmadığı yönündedir. Gerçi bu belirleme uygulama eksikliği olan tüm bölümler için geçerli olabilir. Öte yandan sektörün talebi mutfakta çalışacak elemanlar üzerine olmuş, gastronom ile ilgili herhangi bir şey dile getirmemişlerdir.

\section{SONUÇ}

Ülkemizde yabancı dilde kullanılan sözcüklere daha fazla ilgi duyulmasından gerek, yeni bölümlerin adlarına gastronomi eklenmiştir. Her ne kadar bu kelime İngilizce'de kullanılsa da konuyla ilgili konuştuğum İngilizce konuşan ülke insanlarl, kendi dillerinde gastronomi kelimesinden ziyade mutfak sanatlarını (culinary arts) kullandıklarını belirtmişler, normal bir ABD, Avusturalya veya İngiliz vatandaşın gastronomi 
kelimesinin anlamını bilemeyeceğini de vurgulamışlardır. ABD'deki okullar incelendiğinde bölüm adlarının Gastronomiyi genelde içermediği ve bölüm adlarının "Mutfak Sanatları" olduğu da rahatlıkla görülebilir. Elbette ABD tek başına bir örnek olamaz. Ancak gastronomi kelimesinin anlamından yola çıkılarak, okullarımızda tadıma yönelik ne gibi derslerin olduğu da incelenmelidir. Bu açıdan bölüm adlarının şu an için yanlış kurgulandığı sonucu ortaya çıkmaktadır. Ülkemizde karşılığı olan ve iyi bir meslek icra alanını tam olarak anlatan zanaat kelimesi, sanırım bölüm adlarında "Mutfak Zanaatları" olarak daha anlamlı olurdu. Tabi ismini sağlam koymakla da iş bitmemektedir. Sadece bölüm adları ile oynanarak iyi mutfak zanaatkârları çıkarmak, lisans eğitiminde mümkün değildir.

Kısa bir değerlendirme yapılacak olursa, "Gastronomi ve Mutfak Sanatları" bölümlerinde aslında Yiyecek-İçecek İşletmeciliği" ne yönelik bir eğitim verildiği görülebilir. Bunun en büyük nedenlerinden biri de mutfağ kurulmuş olmasıdır. Bölümlerin açılışında mutfak ile ilgili sınırlamaların olmaması, programların sayısını artırmaktadır. Mevcut koşullar altında bu bölümlerden "Gastronom" yetiştirmek özellikle kamu ve hatta birçok özel üniversite için olası olmadığı gibi iyi mutfak zanaatkârlarını yetiştirmek te çok zordur. Çalışmanın başında da belirtildiği gibi insanoğlu için beslenme gerekliliği her zaman var olacaktır. Bundan dolayı daha nitelikli mutfak zanaatkârlarının yetiştirilmesi gerekmektedir. Fakat bu eğitimin gerçekçi olabilmesi için gerekli kaynakların (insan, donanım, finansman vd.) sağlanması şarttır. Ayrıca bu alana yönelik eğitim müfredatları oluşturulur iken yurt dışında yer alan önemli okulların müfredatları incelenmeli ve sadece kâğıt üstünde kalmayacak şekilde, belirlenen dersleri verebilecek öğretim elemanlarıyla birlikte, uygulamalı eğitimler gerçekleştirilmelidir. Yeni açılacak ve açılmış olan bölümlere mutfak, donanım, malzeme ve nitelikli aşçı açısından sınırlamalar getirilmelidir. Gerekiyorsa bu şartları sağlamayan bölümlerin programlara öğrenci alması durdurulmalıdır. Var olan bölümler gerekli düzeltmeleri yapamaz ve sektörün beklentilerini karşılayamazlar ise sonuçlarının mezunları açısından olumlu olabileceğini düşünmek yanlış olacaktır.

\section{KAYNAKÇA}

Athenaeus (1927). The Deipnosophists. Londra: William Heinemann, https://archive.org/stream/in.ernet. dli.2015.185290/2015.185290.Athenaeus-In-Six-Volumes---I_ djou.txt, Erişim tarihi: 17 Mayıs 2019.

Dorey, F. (2018). Homa Erectus Australian Museum, https://australianmuseum.net.au/learn/science/human-evolution/homo-erectus/, Erişim tarihi: 16 Mayıs 2019.

Gastronomy (2019), https://www.collinsdictionary.com/dictionary/ english/gastronomy, Erişim tarihi: 16 Mayıs 2019.

Gastronomy (2019), https://dictionary.cambridge.org/dictionary/ english/gastronomy, Erişim tarihi: 16 Mayıs 2019.

Gastronomy (2019), https://en.oxforddictionaries.com/definition/ gastronomy, Erişim tarihi: 16 Mayıs 2019.

Gastronomy (2019), https://www.merriam-webster.com/dictionary/gastronomy, Erişim tarihi: 16 Mayıs 2019.

Lawton, G. (2014). Every Human Culture Includes Cooking - This is How it Began, https://www.newscientist.com/articlel mg23230980-600-what-was-the-first-cooked-meal/ , Erişim tarihi: 16 Mayıs 2019.

Shahack-Gross, R., Berna, F., Karkanas, P., Lemorini, C., Gopher, A. ve Barkai, R. (2014). Evidence for The Repeated Use of a Central Hearth at Middle Pleistocene (300 Ky Ago) Qesem Cave, Journal of Archaeological Science, 44: 12-21.

Santich, B. (2004). The Study of Gastronomy and its Relevance to Hospitality Education and Training, International Journal of Hospitality Management, 23 (1): 15-24.

Wong, K. (2013). Case for (Very) Early Cooking Heats Up. Scientific American, https://www.scientificamerican.com/article/case-forvery-early-cooking-heats-up/? redirect=1, Erişim tarihi: 16 Mayıs 2019.

Özkan TÜTüNCÜ, Prof. Dr., Dokuz Eylül Üniversitesi, Spor Bilimleri Fakültesi, Rekreasyon Bölümü.

E-posta: ozkan.tutuncu@deu.edu.tr

ORCID: 0000-0002-2482-0893 